\title{
Responses of Vertebrate Wildlife to Oil and Natural Gas Development: Patterns and Frontiers
}

\author{
A. D. Chalfoun ${ }^{1}$ (D) \\ Accepted: 12 April 2021 / Published online: 7 May 2021 \\ (C) This is a U.S. government work and not under copyright protection in the U.S.; foreign copyright protection may apply 2021
}

\begin{abstract}
Purpose of Review Anthropogenic activities can lead to the loss, fragmentation, and alteration of wildlife habitats. I reviewed the recent literature (2014-2019) focused on the responses of avian, mammalian, and herpetofaunal species to oil and natural gas development, a widespread and still-expanding land use worldwide. My primary goals were to identify any generalities in species' responses to development and summarize remaining gaps in knowledge. To do so, I evaluated the directionality of a wide variety of responses in relation to taxon, location, development type, development metric, habitat type, and spatiotemporal aspects.

Recent Findings Studies $(n=70)$ were restricted to the USA and Canada, and taxonomically biased towards birds and mammals. Longer studies, but not those incorporating multiple spatial scales, were more likely to detect significant responses. Negative responses of all types were present in relatively low frequencies across all taxa, locations, development types, and development metrics but were context-dependent. The directionality of responses by the same species often varied across studies or development metrics.

Summary The state of knowledge about wildlife responses to oil and natural gas development has developed considerably, though many biases and gaps remain. Studies outside of North America and that focus on herpetofauna are lacking. Tests of mechanistic hypotheses for effects, long-term studies, assessment of response thresholds, and experimental designs that isolate the effects of different stimuli associated with development, remain critical. Moreover, tests of the efficacy of habitat mitigation efforts have been rare. Finally, investigations of the demographic effects of development across the full annual cycle were absent for non-game species and are critical for the estimation of population-level effects.
\end{abstract}

Keywords Amphibians · Birds · Mammals · Natural gas development · Oil · Wildlife

\section{Introduction}

Global demand for energy continues to increase [1, 2], and substantial portions of that demand will be met with natural gas extraction and on-going oil production $[3,4 \bullet]$. In particular, unconventional oil and natural gas extraction is becoming a major energy sector worldwide [1], though currently is conducted primarily within the USA and Canada $[2,5]$. New

This article is part of the Topical Collection on Interface of Landscape Ecology and Natural Resource Management

\footnotetext{
A. D. Chalfoun

achalfou@uwyo.edu

1 U.S. Geological Survey Wyoming Cooperative Fish and Wildlife Research Unit, Department of Zoology \& Physiology, and Program in Ecology, University of Wyoming, 1000 East University Avenue, Department 3166, Laramie, WY 82071, USA
}

extraction technologies are facilitating rapid development in previously pristine landscapes, which has raised concerns for sensitive species $[3,4 \bullet, 5,6]$. Similar to other forms of humaninduced rapid environmental change, the process of extracting fossil fuels has the capability to rapidly and extensively transform landscapes before wildlife can adapt [6, 7]. Landscape changes that result from oil and natural gas development include habitat loss, fragmentation, and alteration; chemical pollution, and the addition or amplification of novel stimuli such as human traffic, noise, and light [5, 6, 8, 9]. Delineation of the effects of such changes is therefore timely and critical for the effective mitigation of habitats, and wildlife conservation.

My review was preceded by several thorough and insightful reviews on various aspects of energy development and wildlife, which set the stage for the examination of progress and remaining frontiers. Most examinations of development effects at the time of previous reviews documented negative effects of extraction activities [1]. Empirical studies, however, 
were conducted primarily within North America, albeit very few within the forests of the eastern USA [1, 2]. Moreover, studies were biased taxonomically towards non-volant mammals and, to a lesser extent, birds [1,2]. Species of economic importance such as ungulates and greater sage-grouse received more focus in field studies than non-game species [1, $2,9]$. Mammalian responses were primarily behavioral, including space use and patterns of movement, whereas avian evaluations centered on changes in abundance within the vicinity of development [1]. Few generalizations about patterns of wildlife responses to oil and natural gas development had emerged, however, and effects were characterized as area and species specific [1].

Authors of previous reviews articulated many frontiers in understanding, in addition to addressing geographic and taxonomic gaps. Because energy development simultaneously alters landscapes in many ways, authors reasoned that the disentangling of responses to multiple factors deserved further attention [2], as did the quantification of both direct and indirect effects $[5,10,11]$. Accordingly, from a methodological standpoint, researchers encouraged the incorporation of baselines (e.g., before-after, control-impact designs) such that the effects of development could be isolated definitively $[5,11]$. Another insightful suggestion with clear implications for management was the examination of potential thresholds above which responses to development occur [1]. Physical habitat changes such as those imposed by development, moreover, do not occur in isolation. Thus, understanding the cumulative effects of oil and natural gas development in combination with other contemporary stressors such as climatic variability also is critical $[1,6]$. From a spatiotemporal perspective, authors emphasized the analysis of effects at multiple spatial scales and across sufficient time periods such that potential lag effects could be detected $[5,11]$. The importance of studying a species across the full annual cycle also was articulated, so that ultimately demographic effects can be connected to actual population dynamics $[1,4 \bullet]$. Finally, oil and natural gas development has a finite lifespan, and operators are usually required to implement reclamation measures following well completion. The efficacy of potential mitigation measures, however, had received little study $[1,5]$.

Herein, I revisit and build upon existing reviews of the effects of oil and natural gas development on vertebrate wildlife to determine the extent to which previously articulated gaps were addressed and additional patterns have emerged. I reviewed the recent literature focused on energy development and responses of birds, mammals, reptiles, and amphibians and summarized patterns (including the directionality of responses) by taxon, location, development type, development metric, response type, and habitat type. Because responses to landscape change can manifest at different scales, moreover, I investigated whether the duration of studies or number of spatial scales assessed influenced the detection of responses, and documented evidence of threshold effects. Additionally, for species with multiple tests, I assessed the congruence in species' responses to development across contexts (locations, development metrics, and response type) to determine the consistency and predictability of responses. Finally, I discuss remaining frontiers in understanding that emerged from the review.

\section{Approach}

I conducted a literature search using the search engine Biological Abstracts for papers focused on oil and/or natural gas extraction and wildlife during the years 2014-2019. I first used the following wildlife search terms: wildlife, bird*, mammal*, avian, amphibian*, reptile*, lizard*, herp*, combined sequentially with all of the following development terms: energy development, gas and development, natural gas, oil and development, frack*, and shale gas. I then conducted a secondary search focused on the combination of energy development metrics with the response terms: occupancy, abundance, richness, diversity, habitat selection, habitat use, avoidance, reproduc*, and mortality. Results were refined taxonomically to Mammalia, Aves, Reptilia, and Amphibia.

I focused on the effects of changes to terrestrial habitats (e.g., no aquatic contaminant or oil spill studies). I did not include investigations of mining (e.g., "oil sands") as they have very different footprints compared with energy fields. I also omitted papers exclusively focused on roads, seismic or power lines, as those landscape changes are more universal than oil and natural gas development per se. I focused on studies with empirical (field) components and omitted purely modeling papers. Papers had to focus on the current effects of development on species, not just model future impacts based on projected habitat changes, or post hoc attributions to development. No artificial nest studies or laboratory experiments were included (i.e., animals must have been studied in situ). Finally, I did not include papers in which species were pooled for analyses, with the exception of diversity and richness analyses and one paper focused on amphibian deformities throughout the USA [12•].

For each study adhering to review criteria, I extracted the following information: author(s), year, journal, taxon, species, country, state or province, habitat type (forest, shrubland, grassland, wetland, mixed), development type (oil, natural gas, or both), season (spring, summer/breeding, fall, winter), study duration in years, response type(s), and development metric(s). I recorded also the number of summary scales within which development metrics were calculated, the inclusion of other habitat variables and whether they had explanatory power, tests, and presence of threshold effects, the directionality of responses, and suggestions for further study. 
Development metrics included proximity to development, well density, well pad density, and surface disturbance (amount of cleared land associated with development activities). I counted tests of potential thresholds as present when explicitly articulated and/or when quadratic effects were included models in addition to linear. I binned species' responses into the following categories: occurrence/occupancy, abundance/density, fecundity metrics (e.g., clutch size, pregnancy rates, cow-calf ratios), reproductive success (e.g., nest survival, number fledged, juvenile survival), adult survival, behavioral (habitat use, habitat selection, avoidance, site fidelity), body mass and condition metrics, physiological (stress hormones, immunocompetence), disease/ecotoxicological, and richness/diversity metrics.

Each species, development type, development metric, and specific response combination was considered an individual "test." Each paper could therefore contain multiple tests. If responses were evaluated separately for different seasons or at distinct scales (e.g., home range versus within-home range), I recorded each as a separate test. Responses recorded at different times of day, however, were pooled and I recorded whether significant responses were recorded during any part of the day. I used a vote-counting approach and relied on authors' interpretation of which tests were significant or not based on their respective statistical analyses. The use of a vote-counting strategy for my review precluded the ability to calculate the overall magnitude of the effects of development across studies. Many studies did not include the requisite information with which to conduct a meta-analysis, however, which would have decreased the sample size of papers included in my review. The directionality of responses was considered negative or positive if focal metrics (e.g., abundance, survival, etc.) decreased or increased with proximity to development features, well or well pad density, or surface disturbance, respectively, and neutral if authors concluded a lack of significant effect. For multi-year studies, I recorded negative or positive responses if observed during any of the study years (e.g., year by treatment interactions). Finally, I analyzed whether study duration (number of years) or number of spatial scales examined increased the probability of detecting effects of development using binary logistic regression.

\section{Review Summary}

My literature search resulted in a sample of 465 individual tests on 102 species from 69 studies $[12 \cdot, 13-15,16 \bullet$, 17-21, 22•, 23-30, 31•, 32-33, 34•, 35-40, 41•, 42-46, 47•, $48-59,60 \cdot, 61-78,79 \bullet \cdot]$. The majority $(84 \%)$ were focused on birds (44 studies, 389 tests), followed by mammals (22 studies, 67 tests), and amphibians ( 3 studies, 8 tests). One study focused on vertebrate diversity [13]. Of herpetofaunal studies, I located only two studies focused on anurans [12•, $14]$, two on salamanders [14, 15], and none on reptiles. Of the bird studies, 18 focused on passerines, 18 on gallinaceous species, 5 on raptors, 2 on waterfowl, and 1 on a shorebird (Killdeer, Charadrius vociferus) [16॰]. The bird species with the greatest number of tests was the great- er sage-grouse (Centrocercus urophasianus) with 52 tests $\mathrm{X}(N=11$ studies $)$, followed by the chestnut-collared longspur (Calcarius ornatus), with 51 tests from eight studies. Of the mammal papers, the majority focused on ungulates $(N=32$ tests from 14 studies), with three on medium-sized mammals (small canids and mustelids) [17-19], two on the deer mouse [17, 20], one on least chipmunks (Tamias minimus) [21], one on pygmy rabbits (Brachylagus idahoensis) [22•], and one on a large carnivore (grizzly bear, Ursus arctos) [23]. The two mammalian species that received the most study were pronghorn (Antilocapra americana; $N=19$ tests from six studies) and mule deer (Odocoileus hemionus; $N=$ 13 tests from eight studies).

Studies were located exclusively in the USA ( $N=57$ studies and 288 tests) and Canada ( $N=13$ studies, 177 tests). The US studies were conducted within 12 different states (Alaska, California, Colorado, Kansas, Oklahoma, Pennsylvania, Montana, North Dakota, Texas, Utah, West Virginia, and Wyoming). Canadian studies were located primarily in Alberta $(N=10)$, with one each in Saskatchewan and British Columbia, and one that occurred within both Alberta and Saskatchewan. Several geographic hotspots of research focused on oil and natural gas and wildlife emerged, including the forests of the Allegheny plateau in the eastern USA ( $N=7$ studies), the grasslands and arid shrublands of the western USA ( $N=41$ studies), and the grasslands of south-central Canada ( $N=10$ studies). The majority of studies occurred within shrubland $(N=29)$ and grassland $(N=20)$ habitat types, with 10 in forested landscapes, four in wetlands, and 7 in mixed habitats.

In terms of development type, studies were skewed towards natural gas $(N=30$ studies and 240 tests $)$, with 13 studies focused on oil ( $N=106$ tests), and 27 including a combination of both $(N=119$ tests $)$. Proximity to infrastructure received the most study $(N$ $=239$ tests; $51.4 \%)$, followed by well density $(N=95$ tests; $20.4 \%)$, surface disturbance $(N=63$ tests; $13.5 \%)$, well pad density $(N=36$ tests; 7.7\%), and binary (developed versus undeveloped; $N=32$ tests; $6.9 \%$ ). Response metrics were biased towards abundance and density effects $(N=195$ tests; 41.9\%). Behavioral responses, including habitat use and selection, was the second most common response type with 109 (23.4\%) tests. Responses of metrics associated with fitness outcomes combined comprised $24.3 \%$ of tests $(N=113)$. Specifically, tests focused on reproductive success (e.g., nest survival) individually comprised $15.7 \%$ of tests $(\mathrm{N}$ = 73), fecundity metrics comprised $5.6 \%(\mathrm{~N}=26)$, followed by adult survival with $3 \%$ of tests $(N=14)$. 
The remainder of the tests examined responses categorized as occurrence or occupancy ( $N=20$ tests; $4.3 \%)$, body size or condition $(N=9 ; 1.9 \%)$, or species richness or diversity $(N=14 ; 3 \%)$. Three papers $(N=4$ tests) fell into the category of disease and ecotoxicology, including deformities in anurans [12•], disease prevalence and ecotoxicology of pronghorn [24], and exposure to rodenticides in the fisher (Pekania pennanti) [18]. Finally, one test from one paper focused on fecal corticosteroids and progesterone in pronghorn [24] comprised the physiological category.

Spatiotemporal aspects, including study duration, time of year, and the number of spatial extents within which development metrics were summarized, varied across studies. Studies ranged from 1 to 40 years in duration (mean $=4.43 \pm 4.05$ $\mathrm{SD})$. Time of year was biased heavily towards the breeding season $(N=407$ tests or $87.5 \%)$, followed by winter $(N=43$ tests), fall or post-breeding ( $N=6$ tests), spring ( $N=4$ tests), and year-round or multiple seasons $(N=5$ tests). For studies examining the effects of well density, well pad density or surface disturbance ( $N=193$ tests), the number of summary spatial scales ranged from one to nine (mean = $1.68 \pm 1.45 \mathrm{SD}$ ). Models (or model suites) of the effects of energy development often (53\% of cases) included other habitat variables. Threshold effects were examined in 122 tests $(26 \%)$ and 12 studies.

\section{Responses Across Taxa, Development Type, and Development Metrics}

Overall, responses to development in 128 tests $(27.5 \%)$ were negative, 260 (55.9\%) were neutral, and 77 (16.6\%) were positive. The prevalence of negative responses to development increased from birds to mammals and to amphibians (Fig. 1a). The number of tests revealing positive responses was higher for mammals than birds, however, and absent for amphibians (albeit with a comparatively low sample size).

The composition of the directionality of responses was remarkably similar for the three major types of energy development (Fig. 1b). The number of negative responses also was similar across response types, with the highest negative response rates for behavioral tests including habitat selection and avoidance (Fig. 1c). By contrast, species richness and diversity responses often were positive in relation to energy development. With the three fitnessrelated response types collapsed into one, birds displayed negative fitness outcomes in $23.5 \%$ of cases ( $N=98$ tests) compared with $33.3 \%$ in mammals ( $N=15$ tests).
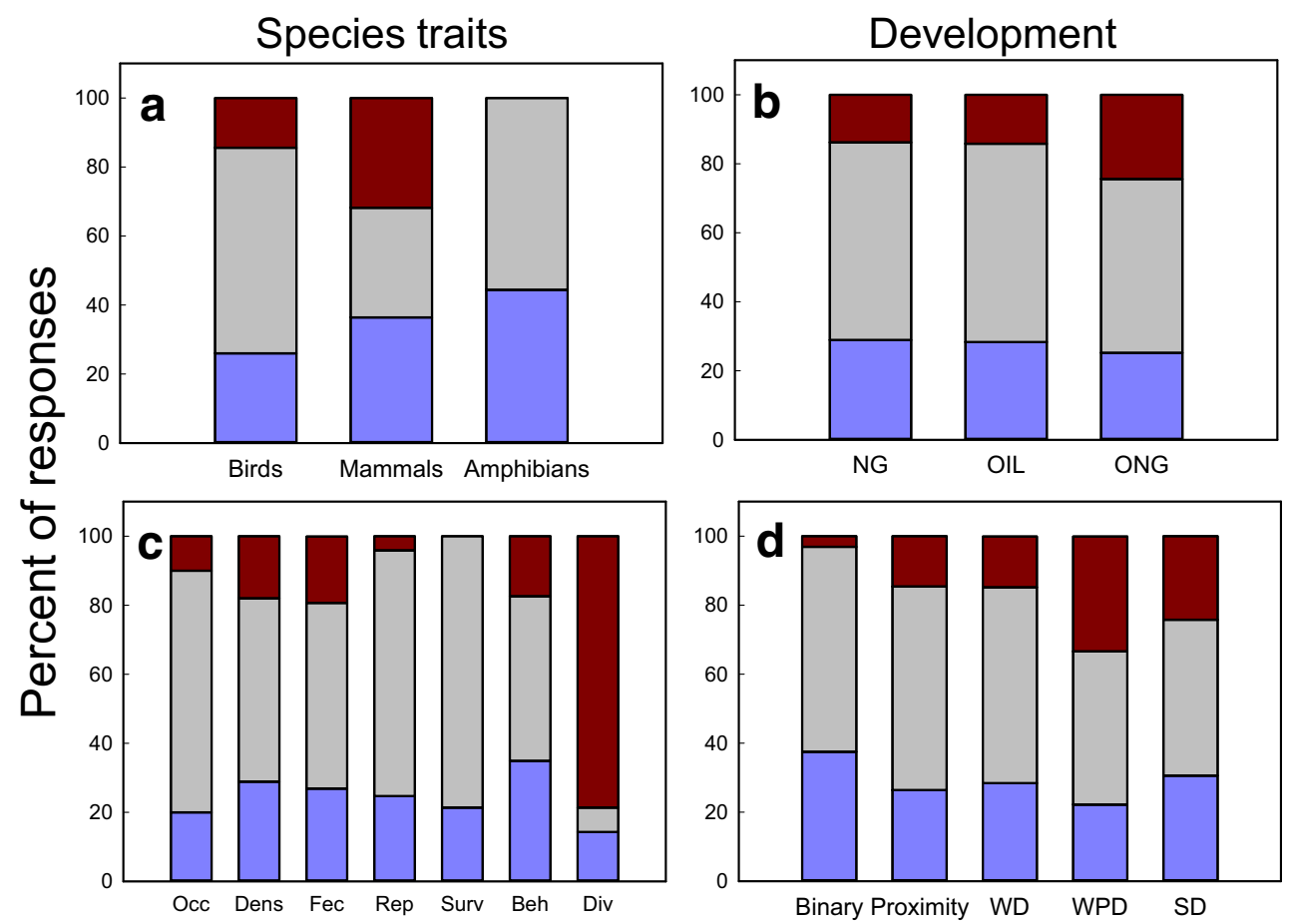

Fig. 1 Prevalence of negative (blue), neutral (grey), and positive (red) responses of wildlife to oil and natural gas development in relation to taxon (a), development type (b), species' response type (c), and development metric (d). Data extracted from a literature search spanning the period 2014-2019. For development type, NG, natural gas; Oil, oil, and ONG, oil and natural gas. For species responses, Occ, tests of occurrence or occupancy; Dens, abundance or density; Fec,

fecundity metrics such as clutch size or pregnancy rates; Rep, measures of reproductive success; Surv, adult survival; Beh, behavioral tests such as habitat use or selection; and Div, richness or diversity. Development metrics include binary (developed versus undeveloped), proximity (to development features such as wells), well density (WD), well pad density (WPD), and surface disturbance (SD). 
Mammals also had a relatively high negative response rate (48.4\%) for behavioral traits including habitat selection and avoidance ( $N=31$ tests). Responses related to body condition and size yielded no negative effects, but rather were neutral in $77.8 \%$ of cases $(N=9)$. For the one physiologically oriented test, pronghorn wintering in Wyoming did not have higher fecal corticosteroids or progesterone in developed versus undeveloped sites [24]. Finally, in terms of disease and ecotoxicology studies, pronghorn in Wyoming did not differ in disease prevalence or ecotoxicological measures between developed and undeveloped areas [24], and fisher exposure to rodenticides was unrelated to oil and natural gas variables [18]. The prevalence of deformities in anurans in the USA, however, increased in areas with oil and natural gas wells $[12 \bullet]$.

Species tended to respond more negatively to binary tests of developed versus undeveloped landscapes compared with other development metrics (Fig. 1d). The percentage of negative responses ranged from $22.2 \%$ negative in relation to well pad density to $37.5 \%$ for binary tests. Birds, in particular, tended to respond negatively to binary tests of development, with $44 \%$ of tests $(N=25)$ producing negative responses compared with tests focused on mammals, which produced only $14.3 \%$ negative responses $(N=7 ; 83.7 \%$ were neutral). Mammals responded most negatively to the proximity of development ( $60 \%$ of tests were negative; $N=15$ ) and surface disturbance ( $40 \% ; N=25$ tests).

The habitat type within which tests were conducted did not strongly influence the directionality of responses. The percentage of negative responses to development was $24.3 \%$ in forests, $24.9 \%$ in grassland, and $33.6 \%$ in shrubland. Negative responses were most common in wetlands (83.3\%) albeit with a limited sample size ( $N=6$ tests). The density of river otters (Lontra canadensis) was negatively associated with natural gas development in Wyoming, USA [19]. Moreover, the larval abundance of barred tiger salamanders (Ambystoma mavortium), boreal chorus frogs (Pseudacris maculata), and northern leopard frogs (Lithobates pipiens) in Montana and North Dakota decreased with the density of oil wells installed prior to 1982 when brines were disposed into groundwater [14].

The time of year during which tests were conducted produced some variation in the directionality of responses. There were only four tests conducted during the spring or prebreeding season, two each on the habitat use of grizzly bears [23] and greater prairie chickens (Tympanuchus cupido) [25], none of which yielded negative responses. The vast majority $(N=406)$ of tests occurred within the summer and/or breeding months, for which $22.6 \%$ of responses were negative. Tests conducted in the fall period $(N=6)$ produced a negative response rate of $16.7 \%$. Negative responses were most common during the winter months $(39.5 \% ; N=43)$.

\section{Spatiotemporal Effects on Responses}

Thirteen studies spanned 10 years or more. The probability of detecting significant effects of energy development, in either direction, increased with study duration (logistic regression; Wald $=4.48, d f=1, P=0.03$ ). The mean number of years for tests producing significant effects was $4.89 \pm 4.88 \mathrm{SD}$ compared with 4.07 years $\pm 3.19 \mathrm{SD}$ for non-significant results. The average study duration associated with detection of negative effects was longer, however ( 5.43 years $\pm 5.72 \mathrm{SD}$ ). The number of spatial scales assessed with respect to species' responses to surrounding well density, well pad density or surface disturbance ( $N=192$ tests) did not increase the probability of detecting significant effects (logistic regression; Wald = $0.25, d f=1, P=0.62$ ).

\section{Threshold Effects}

Of the 123 tests of potential threshold responses, 44 produced negative effects of development and 15 yielded positive effects. Of those significant results, $21(48 \%)$ and five (33\%), respectively, had associated thresholds. For example, the presence and abundance of pygmy rabbits declined sharply after approximately $2 \%$ surface disturbance associated with natural gas development [22•], and lek counts of greater sage-grouse decreased non-linearly, with an inflection point of approximately 4 wells $/ \mathrm{km}^{2}$ [26].

\section{Context-Dependent Responses}

Many species $(N=59)$ were the focus of more than one test, both within or across studies, which facilitated a more indepth evaluation of the consistency of responses to energy development across contexts. Fourteen species, all avian, demonstrated similar responses (mostly neutral) to the same development metric across two or more studies with unique study areas (Table 1). This pattern was not the norm, however. In 30 other cases, species showed different directionality of response across studies. The habitat selection patterns of greater sage-grouse, for example, varied across studies in relation to the proximity to development, well density, well pad density and surface disturbance. A few grassland songbirds, including chestnut-collared longspurs, horned larks (Eremophila alpestris), and Savannah sparrows (Passerculus sandwichensis), and pronghorn demonstrated the full range of potential responses (negative, null, or positive) across contexts.

Determining whether a species tends to respond similarly to development across response types can provide insight into the cumulative effects of development. I found 22 cases in which different response types of the same species were evaluated with respect to the same development metric (Table 2). Congruence occurred for only 11 species-development metric 
Table 1 Consistency in the directionality of species' responses to oil and natural gas development across studies

\begin{tabular}{|c|c|c|c|c|}
\hline Species & Development metric & Response & Direction & References \\
\hline \multicolumn{5}{|l|}{ Congruent responses: } \\
\hline American robin & Proximity & Abundance & + & {$[27,28]$} \\
\hline Black and white warbler & Proximity & Abundance & 0 & {$[27,28]$} \\
\hline Chipping sparrow & Proximity & Abundance & + & {$[27,28]$} \\
\hline Clay-colored sparrow & Proximity & Abundance & 0 & {$[29,30]$} \\
\hline Eastern towhee & Proximity & Abundance & 0 & {$[27,28]$} \\
\hline Eastern wood pewee & Proximity & Abundance & + & {$[27,28]$} \\
\hline Horned lark & Proximity & Abundance & 0 & {$[29,31 \bullet]$} \\
\hline Ovenbird & Proximity & Abundance & - & {$[27,28]$} \\
\hline Red-eyed vireo & Proximity & Abundance & - & {$[27,28]$} \\
\hline Ferruginous hawk & Proximity & Nest success & 0 & {$[32,33]$} \\
\hline Greater sage-grouse & Proximity & Nest success & 0 & {$[34 \cdot, 35]$} \\
\hline Northern bobwhite & Proximity & Habitat selection & 0 & {$[36,37]$} \\
\hline Baird's sparrow & Well density & Abundance & 0 & {$[29,31 \bullet]$} \\
\hline Sprague's pipit & Well density & Abundance & 0 & {$[29,31 \cdot, 38]$} \\
\hline Greater sage-grouse & Well density & Nest success & 0 & {$[34 \cdot, 35]$} \\
\hline Greater sage-grouse & Surface disturbance & Nest success & 0 & {$[34 \cdot, 35]$} \\
\hline Greater sage-grouse & Surface disturbance & Survival & 0 & {$[34 \bullet, 39]$} \\
\hline \multicolumn{5}{|l|}{ Contrasting responses } \\
\hline American redstart & Proximity & Abundance &,+ 0 & {$[27,28]$} \\
\hline Baird's sparrow & Proximity & Abundance &,- 0 & {$[29,30,31 \cdot, 40]$} \\
\hline Black-throated-green warbler & Proximity & Abundance &,- 0 & {$[27,28]$} \\
\hline Blue-headed vireo & Proximity & Abundance &,- 0 & {$[27,28]$} \\
\hline Blue jay & Proximity & Abundance &,- 0 & {$[27,28]$} \\
\hline Brown-headed cowbird & Proximity & Abundance &,+ 0 & {$[27-30]$} \\
\hline Chestnut-collared longspur & Proximity & Abundance &,- 0 & {$[29.30,31 \cdot, 38]$} \\
\hline Common yellowthroat & Proximity & Abundance &,+ 0 & {$[27,28]$} \\
\hline Grasshopper sparrow & Proximity & Abundance &,- 0 & {$[25,30,31 \bullet]$} \\
\hline Indigo bunting & Proximity & Abundance &,+ 0 & {$[27,28]$} \\
\hline Savannah sparrow & Proximity & Abundance & $-, 0,+$ & {$[29,30,38,40,41 \bullet]$} \\
\hline Scarlet tanager & Proximity & Abundance &,- 0 & {$[27,28]$} \\
\hline Sprague's pipit & Proximity & Abundance &,- 0 & {$[29,30.31 \cdot 38,40]$} \\
\hline Vesper sparrow & Proximity & Abundance &,+ 0 & {$[29,31 \cdot 38,41 \bullet]$} \\
\hline Western meadowlark & Proximity & Abundance &,+ 0 & {$[29,30,38,40]$} \\
\hline Chestnut-collared longspur & Proximity & Clutch size &,- 0 & {$[38,42,43]$} \\
\hline Chestnut-collared longspur & Proximity & Nest success &,- 0 & {$[38,41 \cdot 42.43]$} \\
\hline Savannah sparrow & Proximity & Nest success & $-, 0,+$ & {$[38,40,41 \cdot, 42]$} \\
\hline Vesper sparrow & Proximity & Nest success &,- 0 & {$[38,40,41 \bullet]$} \\
\hline Greater sage-grouse & Proximity & Survival &,- 0 & {$[34 \bullet, 39]$} \\
\hline Greater sage-grouse & Proximity & Habitat selection &,- 0 & {$[34 \cdot, 39,44,45]$} \\
\hline Pronghorn & Proximity & Habitat selection & $-, 0,+$ & {$[46,47 \bullet \bullet, 48]$} \\
\hline Brown-headed cowbird & Well density & Abundance &,+ 0 & {$[29,49]$} \\
\hline Chestnut-collared longspur & Well density & Abundance & $-, 0,+$ & {$[29,31 \cdot 38]$} \\
\hline Horned lark & Well density & Abundance & $-, 0,+$ & {$[29,31 \bullet]$} \\
\hline Savannah sparrow & Well density & Abundance &,- 0 & {$[29,31 \cdot 38]$} \\
\hline Greater sage-grouse & Well density & Habitat selection &,- 0 & {$[34 \cdot, 39,50]$} \\
\hline Greater sage-grouse & Well pad density & Habitat selection &,- 0 & {$[44,45]$} \\
\hline Brown-headed cowbird & Surface disturbance & Abundance &,- 0 & {$[51]$} \\
\hline Greater sage-grouse & Surface disturbance & Habitat selection &,- 0 & {$[34 \bullet, 39]$} \\
\hline
\end{tabular}

Data derived from a literature search spanning 2014-2019. Null responses denoted with zeros, and negative and positive responses by minus and plus signs, respectively

combinations (seven species of birds, and three mammals). All were consistently neutral responses except for two cases. Pronghorn increased habitat use and had more fawns per doe closer to oil wells [46]. In contrast, both the occupancy and abundance of pygmy rabbits decreased with surface disturbance [22 $]$. In the majority of cases $(N=21)$, however, responses varied across response metrics for nine bird species and one mammal (deer mouse, Peromyscus maniculatus) (Table 2). In several cases, birds either preferred to nest (killdeer) [16•] or had higher densities of nests (northern pintail, Anas acuta; vesper sparrow, Pooecetes gramineus) in areas that conferred lower nest survival $[41 \bullet, 53]$.

Finally, examination of the patterns of the same species' responses to different development metrics within the same study permitted an evaluation of whether particular metrics consistently tended to yield more negative effects, while controlling for study context. Furthermore, negative responses to all assessed metrics of development could suggest an overall higher sensitivity of a species to development. The most common pairing was the inclusion of both proximity and well 


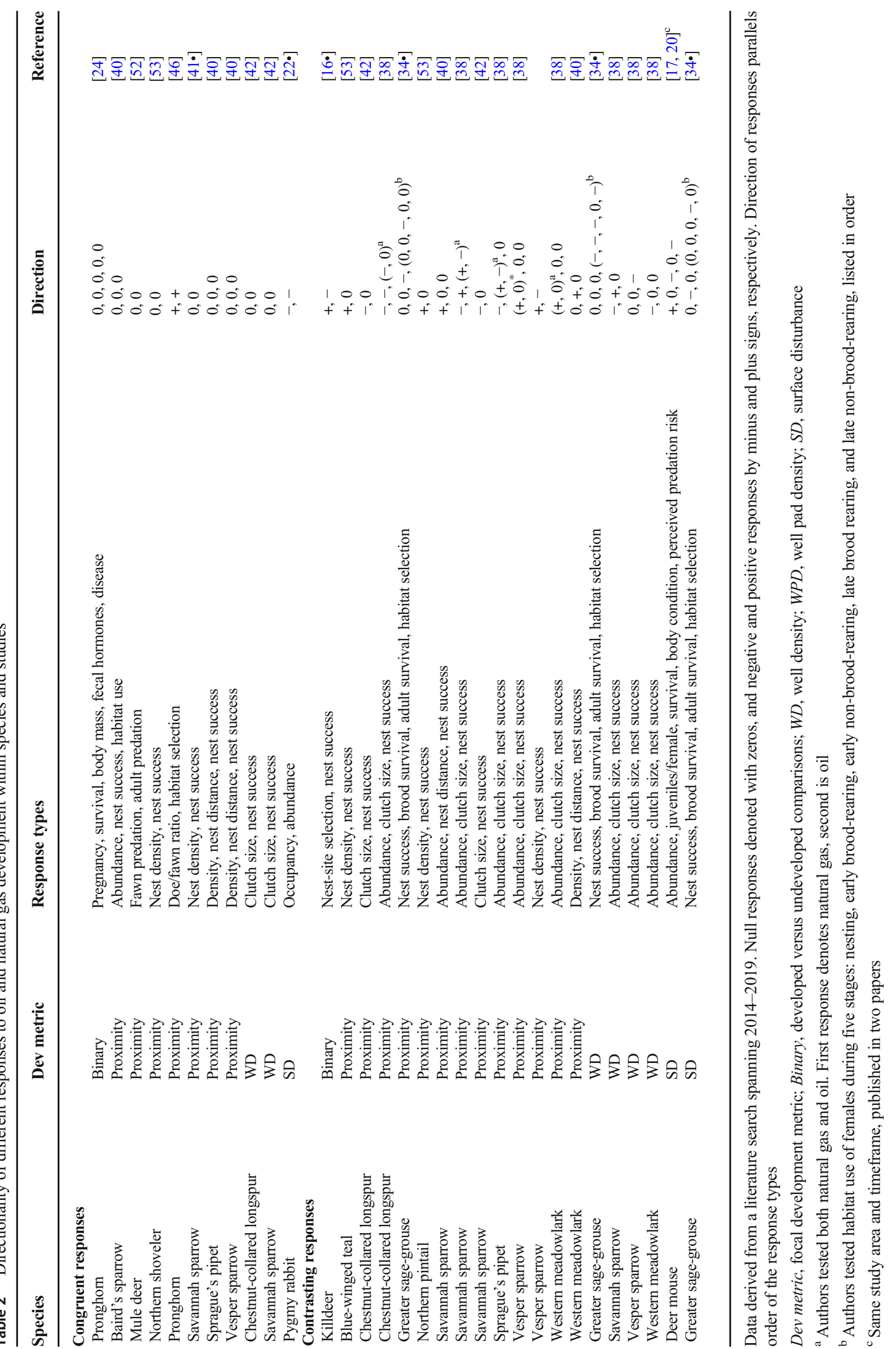


density within the same study. The directionality of different responses within studies was congruent in 28 of 57 cases (Table 3$)$. For the majority of those $(N=20)$, responses were consistently neutral. Several open-country birds, however, responded negatively to two indices of development. Lek attendance by male greater sage-grouse decreased with both well density and surface disturbance [26]. Moreover, sagegrouse avoided areas in closer proximity to natural gas infrastructure and with higher well pad density [44]. The nest survival of chestnut-collared longspurs [38], sage thrashers (Oreoscoptes montanus) [55], savannah sparrows [38], and vesper sparrows [41 $]$ all decreased with two indices of development (Table 3 ). In addition, one forest songbird, the Louisiana waterthrush (Parkesia motacilla), experienced lower nest survival in developed versus undeveloped areas and with respect to surrounding surface disturbance [54]. Finally, pronghorn increased avoidance of natural gas development over time as assayed by both binary and proximity responses $[47 \bullet \bullet]$.

For the remaining 29 tests, species often responded negatively to one but not all indices of development (Table 3). Responses were not consistently negative more often for particular indices compared to another, although some generalities emerged. The abundance of open country birds, including greater sage-grouse and a large suite of grassland songbirds, tended to decrease more with proximity to development compared with surrounding well or well pad density (Table 3). More broadly, in studies with contrasting responses to proximity versus surrounding density tests, species were approximately equally likely to respond more negatively to the proximity of development compared with well density or well pad density.

\section{Remaining Frontiers}

Several themes emerged regarding suggested lines of future inquiry. Many authors ( $N=26$ papers) mentioned the need to better understand the mechanisms underlying species' responses to oil and natural gas development. Understanding the processes underlying observed patterns holds particular value for formulating effective mitigation measures. As a case study, sagebrush songbirds nesting within natural gas fields experienced higher nest predation rates, which was associated with increased densities of synanthropic rodents attracted to the reseeded areas around well pads and pipelines [17, 20,21]. Reproductive success of songbirds would therefore likely benefit from the reduction of initially disturbed soils and/or reclamation practices that more closely mimic initial conditions. The extraction of fossil fuels is a temporary activity on the landscape. In theory, provided sufficient resources, and expertise, habitat could therefore be restored to resemble predisturbance conditions. Surprisingly, however, only two papers astutely pointed out the need to understand the responses of wildlife to post-development restoration [27, 50].
Substantial progress has been made since previous reviews in terms of the investigation of fitness outcomes of species in response to energy development. Regardless, the second most popular theme in terms of suggestions for future study was better understanding of the fitness consequences of wildlife coexisting with development ( $N=19$ papers). Moreover, in my review I characterized increased abundance as a "positive" response, yet the fitness consequences of potentially forcing more individuals into less, or poorer quality, habitat because of development remains unclear [47••]. Additionally, whereas investigation of the effects of landscape change across the full annual cycle is effort and resource-intensive, without such data the effects of habitat changes cannot be accurately extrapolated to source-sink dynamics [34•] or population-level impacts more generally [4•]. With the exception of several mammalian species and the greater sage-grouse, study of species' responses for periods outside the breeding season were extremely rare. The vast majority of North American birds, for example, are seasonal migrants. Whether habitat changes on breeding grounds associated with energy development carry over to influence survival during subsequent periods remains unclear. No studies that I reviewed focused on the effects of development on the post-fledging period for altricial birds. Moreover, whereas estimation of adult survival in relation to development was common for gallinaceous birds that can accommodate larger tracking devices, only one study estimated the annual survival and site fidelity of a migratory passerine (Louisiana waterthrush) [60•]. Finally, although a focus of previous studies and reviews $[2,10,61]$, I did not locate any studies that were focused on the direct mortality of wildlife associated with development.

Long-term studies can facilitate the assessment of the population-level impacts of development, especially those that span pre- and post-development periods [47••]. Accordingly, authors of nine papers recommended more long-term studies. Indeed, the longer-term studies that I reviewed were more likely to document effects of development on wildlife, and many revealed negative effects on several high-profile species including greater sage-grouse, pronghorn, mule deer and woodland caribou (Rangifer tarandus caribou) [26, 47••, 69-78, 79••]. Moreover, the trend remains that very few studies of oil and natural gas development have utilized Before-After-ControlImpact (BACI) designs to account for potentially confounding factors. Accordingly, the need for more BACI analyses was suggested repeatedly ( $N=8$ papers).

The identification of thresholds, or inflection points, in species' responses to development and other forms of landscape change can be particularly informative for conservation practitioners. Whereas some authors in the current review explicitly tested for such thresholds, they were in the minority. Many authors ( $N=6$ papers) therefore encouraged future study of potential non-linear effects of development. Other suggestions ( $N=7$ papers) reflected the need for improved understanding of spatial aspects, including effects at multiple 
Table 3 Species' responses to different oil and natural gas development ("Dev") metrics within the same study

Congruent responses

\begin{tabular}{|c|c|c|c|c|c|}
\hline Baird's sparrow & Abundance & NG & Proximity, WD & 0,0 & {$[29]$} \\
\hline Chestnut-collared longspur & Abundance & NG & Proximity, WD & 0,0 & {$[29]$} \\
\hline Clay-colored sparrow & Abundance & NG & Proximity, WD & 0,0 & {$[29]$} \\
\hline Savannah sparrow & Abundance & NG & Proximity, WD & 0,0 & {$[29]$} \\
\hline Sprague's pipit & Abundance & NG & Proximity, WD & 0,0 & {$[31 \cdot]$} \\
\hline Savannah sparrow & Abundance & ONG & Proximity, WD &,-- & {$[38]$} \\
\hline Greater sage-grouse & Abundance & ONG & $\mathrm{WD}, \mathrm{SD}$ &,-- & {$[26]$} \\
\hline Vesper sparrow & Clutch size & NG & Proximity, WD & 0,0 & {$[38]$} \\
\hline Western meadowlark & Clutch size & NG & Proximity, WD & 0,0 & {$[38]$} \\
\hline Chestnut-collared longspur & Nest success & NG & Proximity, WD &,-- & {$[38]$} \\
\hline Greater sage-grouse & Nest success & NG & Proximity, WD, SD & $0,0,0$ & {$[34 \bullet]$} \\
\hline Greater sage-grouse & Nest success & NG & Proximity, WD, WPD, SD & $0,0,0,0$ & {$[35]$} \\
\hline Louisiana waterthrush & Nest success & NG & Binary, SD &,-- & {$[54]$} \\
\hline Sagebrush sparrow & Nest success & NG & WD, SD & 0,0 & {$[55]$} \\
\hline Sage thrasher & Nest success & NG & $\mathrm{WD}, \mathrm{SD}$ &,-- & {$[55]$} \\
\hline Savannah sparrow & Nest success & NG & Proximity, WD & 0,0 & {$[42]$} \\
\hline Western meadowlark & Nest success & NG & Proximity, WD & 0,0 & {$[38]$} \\
\hline Chestnut-collared longspur & Nest success & Oil & Binary, proximity & 0,0 & {$[41 \cdot]$} \\
\hline Chestnut-collared longspur & Nest success & NG & Proximity, well density & 0,0 & {$[42]$} \\
\hline Sprague's pipit & Nest success & Oil & Binary, proximity & 0,0 & {$[41 \cdot]$} \\
\hline Vesper sparrow & Nest success & Oil & Binary, proximity &,-- & {$[41 \cdot]$} \\
\hline Western meadowlark & Nest success & Oil & Binary, proximity & 0,0 & {$[41 \cdot]$} \\
\hline Ferruginous hawk & No. fledged & ONG & Proximity, WPD & 0,0 & {$[33]$} \\
\hline Greater sage-grouse & Habitat selection & NG & Proximity, WPD &,-- & {$[44]$} \\
\hline Greater sage-grouse & Habitat selection & ONG & Proximity, SD & 0,0 & {$[45]$} \\
\hline Pronghorn & Habitat selection & NG & Binary, proximity &,-- & {$[47 \cdot \bullet]$} \\
\hline Pronghorn & Survival & ONG & Proximity, WD & 0,0 & {$[56]$} \\
\hline Fisher & Rodenticide exposure & ONG & $\mathrm{WD}, \mathrm{SD}$ & 0,0 & {$[18]$} \\
\hline \multicolumn{6}{|l|}{ Contrasting responses } \\
\hline Baird's sparrow & Abundance & NG & Proximity, WD &,- 0 & {$[31 \cdot]$} \\
\hline Chestnut-collared longspur & Abundance & NG & Proximity, WD &,- 0 & {$[31 \cdot]$} \\
\hline Grasshopper sparrow & Abundance & NG & Proximity, WD &,- 0 & {$[31 \cdot]$} \\
\hline Horned lark & Abundance & NG & Proximity, WD & $0,+$ & {$[31 \cdot]$} \\
\hline Horned lark & Abundance & NG & Proximity, WD & $0,-$ & {$[29]$} \\
\hline Savannah sparrow & Abundance & NG & Proximity, WD &,- 0 & {$[31 \cdot]$} \\
\hline Sprague's pipit & Abundance & NG & Proximity, WD &,- 0 & {$[38]$} \\
\hline Vesper sparrow & Abundance & NG & Proximity, WD &,+ 0 & {$[38]$} \\
\hline Western meadowlark & Abundance & NG & Proximity, WD &,+ 0 & {$[29]$} \\
\hline Sprague's pipit & Abundance & ONG & Proximity, WD &,- 0 & {$[29]$} \\
\hline Vesper sparrow & Abundance & ONG & Proximity, WD & $(+, 0)^{\mathrm{a}}, 0$ & {$[38]$} \\
\hline Western meadowlark & Abundance & ONG & Proximity, WD & $(+, 0)^{\mathrm{a}},-$ & {$[38]$} \\
\hline Greater sage-grouse & Abundance & ONG & Proximity, WPD &,- 0 & {$[57]$} \\
\hline Chestnut-collared longspur & Clutch size & NG & Proximity, WD &,- 0 & {$[42]$} \\
\hline Chestnut-collared longspur & Clutch size & ONG & Proximity, WD & $(-,-)^{\mathrm{a}}, 0$ & {$[38]$} \\
\hline Savannah sparrow & Clutch size & NG & Proximity, WD &,- 0 & {$[42]$} \\
\hline Brewer's sparrow & Nest success & NG & $\mathrm{WD}, \mathrm{SD}$ & $0,-$ & {$[55]$} \\
\hline Savannah sparrow & Nest success & Oil & Binary, proximity &,- 0 & {$[41 \cdot]$} \\
\hline Sharptail grouse & Nest success & Oil & Proximity, WD & $0,+$ & {$[58]$} \\
\hline
\end{tabular}


Table 3 (continued)

\begin{tabular}{|c|c|c|c|c|c|}
\hline Species & Response type & Dev type & Dev metrics & Responses & Reference \\
\hline Vesper sparrow & Nest success & ONG & Proximity, WD & $(0,0)^{\mathrm{a}},-$ & {$[38]$} \\
\hline Greater sage-grouse & Brood survival & NG & Proximity, WD, SD & $0,0,-$ & {$[34 \cdot]$} \\
\hline Ferruginous hawk & No. fledged & ONG & Proximity, WD & $0,+$ & {$[32]$} \\
\hline Mule deer & Fawn survival & NG & Binary, proximity & $0,-$ & [59] \\
\hline Greater sage-grouse & Survival & NG & Proximity, WD, SD & $-, 0,0$ & {$[34 \bullet]$} \\
\hline Greater sage-grouse & Habitat selection & ONG & Proximity, WD, SD & $0,0,-$ & [39] \\
\hline Greater sage-grouse & Habitat selection & NG & Proximity, WD, SD & $(0,0,-, 0,0),(-,-,-, 0,-),(0,0,0,-, 0)^{\mathrm{b}}$ & {$[34 \bullet]$} \\
\hline Greater prairie chicken & Habitat selection & Oil & Proximity, WD & $(+, 0,0,0),(0,0,-,-)^{\mathrm{c}}$ & {$[25]$} \\
\hline Northern bobwhite & Habitat selection & ONG & Proximity, WPD & $0,-$ & {$[37]$} \\
\hline Pronghorn & Habitat selection & ONG & Proximity, WD & $(0,-,-),(+, 0,0,0)^{\mathrm{d}}$ & {$[48]$} \\
\hline
\end{tabular}

Data derived from a literature search spanning 2014-2019. Null responses are denoted by zeros, and negative and positive responses are represented by minus and plus signs, respectively. Direction of responses parallels order of the development metrics assessed

$N G$, natural gas development; Oil, oil fields; $O N G$, both oil and natural gas; $W D$, well density; $W P D$, well pad density; $S D$, surface disturbance

${ }^{a}$ Authors examined proximity responses in relation to both development types. First response denotes natural gas, second is oil

${ }^{\mathrm{b}}$ Authors tested habitat use of females during five stages: nesting, early brood-rearing, early non-brood-rearing, late brood rearing, and late non-broodrearing, listed in order

${ }^{\mathrm{c}}$ Authors tested habitat use during four seasons: lekking, nesting, post-breeding, non-breeding, listed in order

${ }^{\mathrm{d}}$ Data are split by home-range scale in summer, patch-scale in winter, home-range in winter for proximity, followed by patch-scale in summer, homerange scale in summer, patch scale in winter, and home range in winter for well density

spatial scales, and the influence of the spatial configuration of development. Indices such as well density or well pad density in some cases may be decoupled from the actual landscape metric inducing changes, such as the amount of habitat loss $[21,55]$. The use of such infrastructure metrics can therefore produce very different results even for similar species within the same system [55].

The need to better understand the additive effects and/or potential synergisms between different characteristics of energy development and other environmental stressors comprised another category of suggestions for future study ( $N=7$ papers). Moreover, the specific stimuli that elicited behavioral responses such as avoidance usually were unknown. The extraction of oil and gas resources entails a multi-step process including siting, infrastructure construction, drilling of wells, production, and completion. No study that I reviewed assessed the relative responses across these stages, which could provide inference regarding the aspects of development that elicit the strongest responses. Notable advances in the study of altered soundscapes resulting from anthropogenic activities are encouraging [80]. Disentangling the specific cues to which wildlife respond, however, remains challenging but can be accomplished via carefully designed empirical studies [41•] and field experiments [81].

\section{Conclusions}

During the period immediately preceding my review, authors lamented a paucity of evaluations of species' responses to oil and natural gas development $[2,5,8]$. Since then, a large number of literatures have focused on how energy development influences a wide variety of wildlife responses. Whereas oil and gas reserves exist on every continent [1], unfortunately studies continue to be highly biased towards North America. The location bias is concerning because regions of high overlap between terrestrial fossil fuel reserves and biodiversity exist on other continents, especially within South America, Africa and Asia [3]. From a taxonomic standpoint, the breadth of mammalian and avian species comprising the focus of development studies has increased; however, studies focused on herpetofauna remain incredibly rare. This is concerning considering that amphibians in the studies I reviewed had the highest proportion of negative responses. Even within the other major taxa, moreover, studies have tended to focus on a relatively small group of species (for example, ungulates in Mammalia). Overall, the proportion of neutral (and even positive) responses of wildlife to development increased compared to previous summaries [1], which may be a result of the taxonomic expansion of studies to species with lower sensitivity thresholds. Negative responses, however, were universally detected (albeit with relatively low frequency) across taxa, locations, and development type, and with respect to different response types and development indices (Fig. 1). Moreover, positive responses to development by some species can have negative downstream consequences for other species, such as the case of increased rodent abundance and the nest predation rates of sagebrush songbirds [17, 20,21].

Whereas the formulation of generalizations about the effects of energy development across species and systems would be ideal 
[4•], my review revealed a continued pattern of species-specific and context-dependent effects [1]. The same species often responded differently to development across studies, and with respect to different metrics of development (Tables 1 and 3). Moreover, the directionality of species' responses often varied across response types (Table 2). Such patterns may evolve once more in-depth study has been conducted for more species. In the meantime, however, assumptions about the responses of particular species across contexts without accompanying data should be interpreted with caution. Unique responses to anthropogenic disturbance by species, moreover, may not be surprising considering that even similar species within the same system have unique evolutionary histories. Researchers should therefore think carefully about which aspects of development are most likely to influence different responses by a species and at which spatial scale, according to that species' natural and life history characteristics.

Acknowledgments The author thanks K. Kosciuch, an anonymous reviewer, and the Chalfoun lab for insightful suggestions on earlier versions of the manuscript. Any use of trade, firm, or product names is for descriptive purposes only and does not imply endorsement by the US Government.

Funding No grant dollars were used to generate this article. Salary to conduct the work was provided by the US Geological Survey, and the University of Wyoming provided institutional support.

\section{Declaration}

Conflict of Interest The author has no conflict of interest to declare.

Human and Animal Rights and Informed Consent This article contains no studies with human or animal subjects performed by the authors.

Open Access This article is licensed under a Creative Commons Attribution 4.0 International License, which permits use, sharing, adaptation, distribution and reproduction in any medium or format, as long as you give appropriate credit to the original author(s) and the source, provide a link to the Creative Commons licence, and indicate if changes were made. The images or other third party material in this article are included in the article's Creative Commons licence, unless indicated otherwise in a credit line to the material. If material is not included in the article's Creative Commons licence and your intended use is not permitted by statutory regulation or exceeds the permitted use, you will need to obtain permission directly from the copyright holder. To view a copy of this licence, visit http://creativecommons.org/licenses/by/4.0/.

\section{References}

Papers of particular interest, published recently, have been highlighted as:

- Of importance

- Of major importance

1. Northrup JM, Wittemyer G. Characterising the impacts of emerging energy development on wildlife, with an eye towards mitigation. Ecol Lett. 2013;16(1):112-25. https://doi.org/10.1111/ele.12009.

2. Jones NF, Pejchar L, Kiesecker JM. The energy footprint: how oil, natural gas, and wind energy affect land for biodiversity and the flow of ecosystem services. Bioscience. 2015;65(3):290-301. https://doi.org/10.1093/biosci/biu224.

3. Butt N, Beyer HL, Bennett JR, Biggs D, Maggini R, Mills M, et al. Biodiversity Risks from Fossil Fuel Extraction. Science. 2013;342(6157):425-6. https://doi.org/10.1126/science.1237261.

4. Loss SR. Avian interactions with energy infrastructure in the context of other anthropogenic threats. Condor. 2016;118(2):424-32. https://doi.org/10.1650/condor-16-12.1. The author of this paper astutely points out some key gaps in understanding about birds and fossil fuel extraction, and articulates some bigger-picture frontiers.

5. Brittingham MC, Maloney KO, Farag AM, Harper DD, Bowen $\mathrm{ZH}$. Ecological risks of shale oil and gas development to wildlife, aquatic resources and their habitats. Environ Sci Technol. 2014;48(19):11034-47. https://doi.org/10.1021/es5020482.

6. Souther S, Tingley MW, Popescu VD, Hayman DTS, Ryan ME, Graves TA, et al. Biotic impacts of energy development from shale: research priorities and knowledge gaps. Front Ecol Environ. 2014;12(6):330-8. https://doi.org/10.1890/130324.

7. Sih A, Stamps J, Yang LH, McElreath R, Ramenofsky M. Behavior as a key component of integrative biology in a human-altered world. Integr Comp Biol. 2010;50(6):934-44. https://doi.org/10. 1093/icb/icq148.

8. Kiviat E. Risks to biodiversity from hydraulic fracturing for natural gas in the Marcellus and Utica shales. In: Schlesinger WH, Ostfeld RS, editors. Year in ecology and conservation biology. Annals of the New York Academy of Sciences. Oxford: Blackwell Science Publ; 2013. p. 1-14.

9. Naugle DE, SpringerLink. Energy development and wildlife conservation in Western North America. vol Book, Whole. Washington, DC Island Press/Center for Resource Economics; 2011.

10. Loss SR, Dorning MA, Diffendorfer JE. Biases in the literature on direct wildlife mortality from energy development. Bioscience. 2019;69(5):348-59. https://doi.org/10.1093/biosci/biz026.

11. Hovick TJ, Elmore RD, Dahlgren DK, Fuhlendorf SD, Engle DM. Evidence of negative effects of anthropogenic structures on wildlife: a review of grouse survival and behaviour. J Appl Ecol. 2014;51(6):1680-9. https://doi.org/10.1111/1365-2664.12331.

12. Haas SE, Reeves MK, Pinkney AE, Johnson PTJ. Continentalextent patterns in amphibian malformations linked to parasites, chemical contaminants, and their interactions. Glob Chang Biol. 2018;24(1):E275-E88. https://doi.org/10.1111/gcb.13908. One of the very few amphibian papers to date focused on anthropogenic features, including energy development, and malformations.

13. Fiehler CM, Cypher BL, Saslaw LR. Effects of oil and gas development on vertebrate community composition in the southern San Joaquin Valley, California. Glob Ecol Conserv. 2017;9:131-41. https://doi.org/10.1016/j.gecco.2017.01.001.

14. Hossack BR, Smalling KL, Anderson CW, Preston TM, Cozzarelli IM, Honeycutt RK. Effects of persistent energy-related brine 
contamination on amphibian abundance in national wildlife refuge wetlands. Biol Conserv. 2018;228:36-43. https://doi.org/10.1016/j. biocon.2018.10.007.

15. Keller DH, Horwitz RJ, Mead JV, Belton TJ. Natural gas drilling in the Marcellus Shale region: well pad densities and aquatic communities. Hydrobiologia. 2017;795(1):49-64. https://doi.org/10.1007/ s10750-017-3112-8.

16. Atuo FA, Saud P, Wyatt C, Determan B, Crose JA, O'Connell TJ. Are oil and natural gas development sites ecological traps for nesting killdeer? Wildl Biol. 2018:wlb.00476. https://doi.org/10. $2981 /$ wlb.00476. One of the only studies to collect the necessary data to test the concept of ecological traps in relation to natural gas development.

17. Sanders LE, Chalfoun AD. Mechanisms underlying increased nest predation in natural gas fields: a test of the mesopredator release hypothesis. Ecosphere. 2019;10(5):e02738. https://doi.org/10. 1002/ecs2.2738.

18. Thomas PJ, Eccles KM, Mundy LJ. Spatial modelling of non-target exposure to anticoagulant rodenticides can inform mitigation options in two boreal predators inhabiting areas with intensive oil and gas development. Biol Conserv. 2017;212(Part A):111-9. https:// doi.org/10.1016/j.biocon.2017.06.005.

19. Godwin BL, Albeke SE, Bergman HL, Walters A, Ben-David M. Density of river otters (Lontra canadensis) in relation to energy development in the Green River Basin, Wyoming. Sci Total Environ. 2015;532:780-90. https://doi.org/10.1016/j.scitotenv. 2015.06.058

20. Sanders LE, Chalfoun AD. Novel landscape elements within natural gas fields increase densities but not fitness of an important songbird nest predator. Biol Conserv. 2018;228:132-41. https://doi.org/ 10.1016/j.biocon.2018.10.020.

21. Hethcoat MG, Chalfoun AD. Towards a mechanistic understanding of human-induced rapid environmental change: a case study linking energy development, nest predation and predators. J Appl Ecol. 2015;52(6):1492-9. https://doi.org/10.1111/1365-2664.12513.

22. Germaine SS, Carter SK, Ignizio DA, Freeman AT. Relationships between gas field development and the presence and abundance of pygmy rabbits in southwestern Wyoming. Ecosphere. 2017;8(5): e01817. https://doi.org/10.1002/ecs2.1817. Very thorough examination of the effects of landscape elements associated with natural gas development on a sensitive non-game species.

23. McKay T, Sahlen E, Stoen O-G, Swenson JE, Stenhouse GB. Wellsite selection by grizzly bears Ursus arctos in west-central Alberta. Wildl Biol. 2014;20(5):310-9. https://doi.org/10.2981/ wlb.00046.

24. Beckmann JP, Olson SH, Seidler RG, Berger J. Sub-lethal effects of energy development on a migratory mammal-the enigma of North American pronghorn. Glob Ecol Conserv. 2016;6:36-47. https:// doi.org/10.1016/j.gecco.2016.02.001.

25. Londe DW, Fuhlendorf SD, Elmore RD, Davis CA, Rutledge J. Female Greater Prairie-Chicken response to energy development and rangeland management. Ecosphere. 2019;10(12):21. https:// doi.org/10.1002/ecs2.2982.

26. Green AW, Aldridge CL, O'Donnell MS. Investigating impacts of oil and gas development on greater sage-grouse. J Wildl Manag. 2017;81(1):46-57. https://doi.org/10.1002/jwmg.21179.

27. Barton EP, Pabian SE, Brittingham MC. Bird community response to Marcellus shale gas development. J Wildl Manag. 2016;80(7): 1301-13. https://doi.org/10.1002/jwmg.21117.

28. Farwell LS, Wood PB, Brown DJ, Sheehan J. Proximity to unconventional shale gas infrastructure alters breeding bird abundance and distribution. Condor. 2019;121(3):20. https://doi.org/10.1093/ condor/duz020.
29. Rodgers JA, Koper N. Shallow gas development and grassland songbirds: the importance of perches. J Wildl Manag. 2017;81(3): 406-16. https://doi.org/10.1002/jwmg.21210.

30. Thompson SJ, Johnson DH, Niemuth ND, Ribic CA. Avoidance of unconventional oil wells and roads exacerbates habitat loss for grassland birds in the North American great plains. Biol Conserv. 2015;192:82-90. https://doi.org/10.1016/j.biocon.2015.08.040.

31. Bogard HJK, Davis SK. Grassland songbirds exhibit variable responses to the proximity and density of natural gas wells. J Wildl Manag. 2014;78(3):471-82. https://doi.org/10.1002/jwmg.684.

Thorough examination of abundance of a suite of grassland songbirds in relation to both proximity and density of development, while accounting for habitat covariates.

32. Keough HL, Conover MR, Roberts AJ. Factors influencing reproductive success of ferruginous hawks in the Uintah Basin. J Raptor Res. 2015;49(2):161-73. https://doi.org/10.3356/0892-1016-49.2. 161.

33. Wallace ZP, Kennedy PL, Squires JR, Olson LE, Oakleaf RJ. Human-made structures, vegetation, and weather influence ferruginous hawk breeding performance. J Wildl Manag. 2016;80(1):7890. https://doi.org/10.1002/jwmg.1000.

34. Kirol CP, Beck JL, Huzurbazar SV, Holloran MJ, Miller SN. Identifying greater sage-grouse source and sink habitats for conservation planning in an energy development landscape. Ecol Appl. 2015;25(4):968-90. https://doi.org/10.1890/13-1152.1. Impressively thorough demographic analysis that culminates in a source-sink map for a species of conservation concern.

35. Kirol CP, Sutphin AL, Bond L, Fuller MR, Maechtle TL. Mitigation effectiveness for improving nesting success of greater sage-grouse influenced by energy development. Wildl Biol. 2015;21(2):98-109. https://doi.org/10.2981/wlb.00002.

36. Tanner EP, Elmore RD, Davis CA, Fuhlendorf SD, Dahlgren DK, Thacker ET, et al. Does the presence of oil and gas infrastructure potentially increase risk of harvest in northern bobwhite? Wildl Biol. 2016;22(6):294-304. https://doi.org/10.2981/wlb.00254.

37. Duquette CA, Davis CA, Fuhlendorf SD, Elmore RD. Northern Bobwhite (Colinus virginianus) space use minimally affected by oil and gas development. Rangel Ecol Manag. 2019;72(3):484 91. https://doi.org/10.1016/j.rama.2018.12.005.

38. Daniel J, Koper N. Cumulative impacts of roads and energy infrastructure on grassland songbirds. Condor. 2019;121(2). https://doi. org/10.1093/condor/duz011.

39. Smith KT, Kirol CP, Beck JL, Blomquist FC. Prioritizing winter habitat quality for greater sage-grouse in a landscape influenced by energy development. Ecosphere. 2014;5(2):15. https://doi.org/10. 1890/es13-00238

40. Ludlow SM, Brigham RM, Davis SK. Oil and natural gas development has mixed effects on the density and reproductive success of grassland songbirds. Condor. 2015;117(1):64-75. https://doi.org/ 10.1650/condor-14-79.1.

41. Bernath-Plaisted J, Koper N. Physical footprint of oil and gas infrastructure, not anthropogenic noise, reduces nesting success of some grassland songbirds. Biol Conserv. 2016;204(Part B):434-41. https://doi.org/10.1016/j.biocon.2016.11.002. Excellent and rare example of an experimental design that teases apart effects of different aspects of development (physical footprint versus noise).

42. Yoo J, Koper N. Effects of shallow natural gas well structures and associated roads on grassland songbird reproductive success in Alberta, Canada. PLoS One. 2017;12(3):e0174243. https://doi. org/10.1371/journal.pone.0174243.

43. Ng CS, Des Brisay PG, Koper N. Chestnut-collared longspurs reduce parental care in the presence of conventional oil and gas 
development and roads. Anim Behav. 2019;148:71-80. https://doi. org/10.1016/j.anbehav.2018.12.001.

44. Holloran MJ, Fedy BC, Dahlke J. Winter habitat use of greater sage-grouse relative to activity levels at natural gas well pads. J Wildl Manag. 2015;79(4):630-40. https://doi.org/10.1002/jwmg. 877.

45. Rice MB, Rossi LG, Apa AD. Seasonal habitat use by greater sagegrouse (Centrocercus urophasianus) on a landscape with low density oil and gas development. PLoS One. 2016;11(10):e0165399. https://doi.org/10.1371/journal.pone.0165399.

46. Christie KS, Jensen WF, Boyce MS. Pronghorn resource selection and habitat fragmentation in North Dakota. J Wildl Manag. 2017;81(1):154-62. https://doi.org/10.1002/jwmg.21147.

47.• Sawyer H, Beckmann JP, Seidler RG, Berger J. Long-term effects of energy development on winter distribution and residency of pronghorn in the Greater Yellowstone Ecosystem. Cons Sci Pract. 2019;1(9):e83. https://doi.org/10.1111/csp2.83 A rare, long-term data set that spans periods before and after development.

48. Reinking AK, Smith KT, Mong TW, Read MJ, Beck JL. Across scales, pronghorn select sagebrush, avoid fences, and show negative responses to anthropogenic features in winter. Ecosphere. 2019;10(5):e02722. https://doi.org/10.1002/ecs2.2722.

49. Thomas EH, Brittingham MC, Stoleson SH. Conventional oil and gas development alters forest songbird communities. J Wildl Manag. 2014;78(2):293-306. https://doi.org/10.1002/jwmg.662.

50. Fedy BC, Kirol CP, Sutphin AL, Maechtle TL. The influence of mitigation on Sage-Grouse habitat selection within an energy development field. PLoS One. 2015;10(4):e0121603. https://doi.org/ 10.1371/journal.pone.0121603.

51. Bernath-Plaisted J, Nenninger H, Koper N. Conventional oil and natural gas infrastructure increases brown-headed cowbird (Molothrus ater) relative abundance and parasitism in mixed-grass prairie. R Soc Open Sci. 2017;4(7):170036. https://doi.org/10. 1098/rsos.170036.

52. Lendrum PE, Northrup JM, Anderson CR, Liston GE, Aldridge $\mathrm{CL}$, Crooks KR, et al. Predation risk across a dynamic landscape: effects of anthropogenic land use, natural landscape features, and prey distribution. Landsc Ecol. 2018;33(1):157-70. https://doi.org/ 10.1007/s10980-017-0590-z.

53. Ludlow SM, Davis SK. Oil and natural gas development influence nest-site selection and nest survival of upland-nesting waterfowl and shorebirds. Wildl Soc Bull. 2018;42(1):57-66. https://doi.org/ 10.1002/wsb.849.

54. Frantz MW, Wood PB, Sheehan J, George G. Demographic response of Louisiana Waterthrush, a stream obligate songbird of conservation concern, to shale gas development. Condor. 2018;120(2):265-82. https://doi.org/10.1650/condor-17-130.1.

55. Hethcoat MG, Chalfoun AD. Energy development and avian nest survival in Wyoming, USA: a test of a common disturbance index. Biol Conserv. 2015;184:327-34. https://doi.org/10.1016/j.biocon. 2015.02.009.

56. Reinking AK, Smith KT, Monteith KL, Mong TW, Read MJ, Beck JL. Intrinsic, environmental, and anthropogenic factors related to pronghorn summer mortality. J Wildl Manag. 2018;82(3):608-17. https://doi.org/10.1002/jwmg.21414.

57. Burkhalter C, Holloran MJ, Fedy BC, Copeland HE, Crabtree RL, Michel NL, et al. Landscape-scale habitat assessment for an imperiled avian species. Anim Conserv. 2018;21(3):241-51. https://doi. org/10.1111/acv.12382.

58. Burr PC, Robinson AC, Larsen RT, Newman RA, Ellis-Felege SN. Sharp-tailed grouse nest survival and nest predator habitat use in North Dakota's Bakken Oil Field. PLoS One. 2017;12(1): e0170177. https://doi.org/10.1371/journal.pone.0170177.
59. Peterson ME, Anderson CR Jr, Northrup JM, Doherty PF Jr. Mortality of mule deer fawns in a natural gas development area. J Wildl Manag. 2018;82(6):1135-48. https://doi.org/10.1002/jwmg. 21476.

60. Frantz MW, Wood PB, Sheehan J, George G. Louisiana Waterthrush (Parkesia motacilla) survival and site fidelity in an area undergoing shale gas development. Wilson J Ornith. 2019;131(1):84-95. https://doi.org/10.1676/18-6 One of very few existing investigations of adult survival in relation to development in a passerine bird. Also one of the few papers focused on the effects of natural gas development in forested habitats.

61. Trail PW. Avian mortality at oil pits in the United States: a review of the problem and efforts for its solution. Environ Manag. 2006;38(4):532-44. https://doi.org/10.1007/s00267-005-0201-7.

62. Bohannon R, Blinnikov M. Habitat fragmentation and breeding bird populations in Western North Dakota after the introduction of hydraulic fracturing. Ann Am Assoc Geogr. 2019;109(5): 1471-92. https://doi.org/10.1080/24694452.2019.1570836.

63. Carlisle JD, Sanders LE, Chalfoun AD, Gerow KG. Raptor nest-site use in relation to the proximity of coalbed-methane development. Anim Biodivers Conserv. 2018;41(2):227-43. https://doi.org/10. 32800/abc.2018.41.0227.

64. Flint PL, Reed JA, Lacroix DL, Lanctot RB. Habitat use and foraging patterns of molting male long-tailed ducks in Lagoons of the Central Beaufort Sea, Alaska. Arctic. 2016;69(1):19-28. https:// doi.org/10.14430/arctic4544.

65. Gregory AJ, Beck JL. Spatial heterogeneity in response of male greater sage-grouse Lek attendance to energy development. PLoS One. 2014;9(6):e97132. https://doi.org/10.1371/journal.pone. 0097132.

66. Mutter M, Pavlacky DC, Van Lanen NJ, Grenyer R. Evaluating the impact of gas extraction infrastructure on the occupancy of sagebrush-obligate songbirds. Ecol Appl. 2015;25(5):1175-86. https://doi.org/10.1890/14-1498.1.

67. Northrup JM, Anderson CR Jr, Hooten MB, Wittemyer G. Movement reveals scale dependence in habitat selection of a large ungulate. Ecol Appl. 2016;26(8):2744-55. https://doi.org/10.1002/ eap.1403.

68. Northrup JM, Anderson CR Jr, Wittemyer G. Quantifying spatial habitat loss from hydrocarbon development through assessing habitat selection patterns of mule deer. Glob Chang Biol. 2015;21(11): 3961-70. https://doi.org/10.1111/gcb.13037.

69. Plumb RT, Lautenbach JM, Robinson SG, Haukos DA, Winder VL, Hagen CA, et al. Lesser prairie-chicken space use in relation to anthropogenic structures. J Wildl Manag. 2019;83(1):216-30. https://doi.org/10.1002/jwmg.21561.

70. Scobie CA, Bayne EM, Wellicome TI. Influence of human footprint and sensory disturbances on night-time space use of an owl. Endanger Species Res. 2016;31:75-87. https://doi.org/10.3354/ esr00756.

71. Spence ES, Beck JL, Gregory AJ. Probability of lek collapse is lower inside sage-grouse Core areas: effectiveness of conservation policy for a landscape species. PLoS One. 2017;12(11):e0185885. https://doi.org/10.1371/journal.pone.0185885.

72. Timmer JM, Butler MJ, Ballard WB, Boal CW, Whitlaw HA. Spatially explicit modeling of lesser prairie-chicken Lek Density in Texas. J Wildl Manag. 2014;78(1):142-52. https://doi.org/10. 1002/jwmg.646.

73. Wallace ZP, Kennedy PL, Squires JR, Oakleaf RJ, Olson LE, Dugger KM. Re-occupancy of breeding territories by ferruginous hawks in Wyoming: relationships to environmental and 
anthropogenic factors. PLoS One. 2016;11(4):e0152977. https:// doi.org/10.1371/journal.pone.0152977.

74. Wood PB, Frantz MW, Becker DA. Louisiana waterthrush and benthic macroinvertebrate response to shale gas development. J Fish Wildl Manag. 2016;7(2):423-33. https://doi.org/10.3996/ 092015-jfwm-084.

75. Dwinnell SPH, Sawyer H, Randall JE, Beck JL, Forbey JS, Fralick GL, et al. Where to forage when afraid: Does perceived risk impair use of the foodscape? Ecol Appl. 2019;29(7):e01972. https://doi. org/10.1002/eap.1972.

76. Christie KS, Jensen WF, Schmidt JH, Boyce MS. Long-term changes in pronghorn abundance index linked to climate and oil development in North Dakota. Biol Conserv. 2015;192:445-53. https://doi.org/10.1016/j.biocon.2015.11.007.

77. Johnson CJ, Ehlers LPW, Seip DR. Witnessing extinction - cumulative impacts across landscapes and the future loss of an evolutionarily significant unit of woodland caribou in Canada. Biol Conserv. 2015;186:176-86. https://doi.org/10.1016/j.biocon.2015.03.012.

78. Johnson HE, Sushinsky JR, Holland A, Bergman EJ, Balzer T, Garner J, et al. Increases in residential and energy development are associated with reductions in recruitment for a large ungulate.
Glob Chang Biol. 2017;23(2):578-91. https://doi.org/10.1111/gcb. 13385.

79.• Sawyer H, Korfanta NM, Nielson RM, Monteith KL, Strickland D. Mule deer and energy development-long-term trends of habituation and abundance. Glob Chang Biol. 2017;23(11):4521-9. https://doi. org/10.1111/gcb.13711 Long-term study spanning pre- and post-development period of natural gas development to test whether a high-profile species (mule deer) acclimates to development over time.

80. Proulx R, Waldinger J, Koper N. Anthropogenic landscape changes and their impacts on terrestrial and freshwater soundscapes. Curr Landsc Ecol Rep. 2019;4. https://doi.org/10.1007/s40823-01900038-4.

81. Mejia EC, McClure CJW, Barber JR. Large-scale manipulation of the acoustic environment can alter the abundance of breeding birds: evidence from a phantom natural gas field. J Appl Ecol. 2019;56(8): 2091-101. https://doi.org/10.1111/1365-2664.13449.

Publisher's Note Springer Nature remains neutral with regard to jurisdictional claims in published maps and institutional affiliations. 